\title{
East Midlands
}

\section{East Midlands population density: by local or unitary authority, 2009}

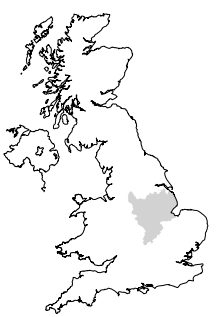

Population density, 2009 (people per sq km)

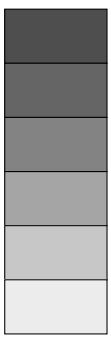

2,500 or over

$1,000-2,499$

$500-999$

$250-499$

$100-249$

99 or under

1 North East

Derbyshire

2 Chesterfield

3 Bolsover

4 Erewash

5 South

Derbyshire

6 Mansfield

7 Ashfield

8 Gedling

9 Broxtowe

10 Nottingham UA

11 Lincoln
12 North West

13 Leicestershire

14 Hinckley and Bosworth

15 Leicester UA

16 Blaby

17 Oadby and

18 Wigston

Northamptonshir

19 Wellingborough

20 Northampton

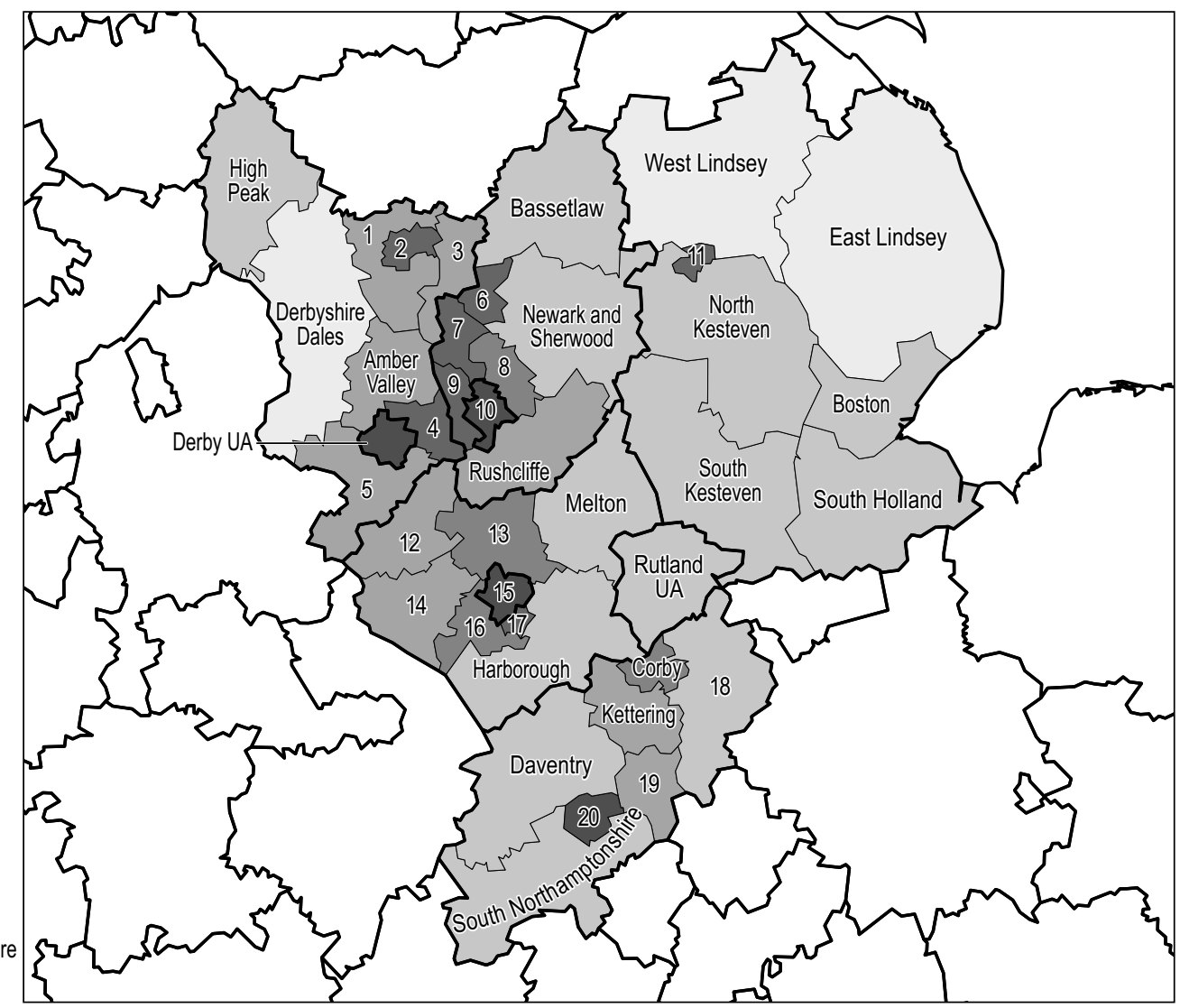

Contains Ordnance Survey data @ Crown copyright and database right 2011

- The East Midlands had a population of 4.5 million in mid-2009, an increase of 3.7 per cent since 2004. This compares with an overall increase of 3.3 per cent for the UK over the same period. (Table 1.2)

- People aged 65 and over in the East Midlands in 2009 made up 16.8 per cent of the population, compared with 18.3 per cent for the under-16s. This compares with averages for the UK of 16.4 per cent and 18.7 per cent respectively. (Table 10.2)

- In the East Midlands men aged 65 in 2007-09 could expect to live another 17.8 years and women 20.4 years. This is the same as the average for the UK. (Table 6.8)

- The unemployment rate in the East Midlands stood at 8.0 per cent in the fourth quarter of 2010 , compared with the UK rate of 7.9 per cent. (Table 1.1)

- A lower proportion of children in the East Midlands (15.5 per cent) lived in workless households in the second quarter of 2010 , than the England average of 15.9 per cent. (Table 8.6)

- In April 2010, the median gross weekly earnings for full-time employees on adult rates who were resident in the East Midlands was $£ 470$, lower than the UK median of $£ 499$. (Table 9.19)

- Labour productivity (gross value added per hour worked) in the East Midlands in 2009 was 7.2 per cent below the UK average. (Table 3.2)

- In the East Midlands, 49.9 per cent of pupils achieved five or more grades $A^{*}-C$ at GCSE level or equivalent including English and mathematics in 2008/09, compared with 49.8 per cent for England as a whole. (Table 4.8)

- Local authorities in the East Midlands recycled or composted 46 per cent of household waste in 2009/10 compared with an England average of 40 per cent. (Table 5.11) 